into both genomic disorders and Mendelizing traits. Genome Res 2013; 23(9): 1395-409.

15 Crawford K, Bracher-Smith M, Owen D, Kendall KM, Rees E, Pardiñas AF, et al. Medical consequences of pathogenic CNVs in adults: analysis of the UK Biobank. J Med Genet 2018, inpress.

16 Kirov G, Rees E, Walters JT, Escott-Price V, Georgieva L, Richards AL, et al. The penetrance of copy number variations for schizophrenia and developmental delay. Biol Psychiatry 2014; 75(5): 378-85.

17 Wagner R. Intelligence, training and employment. Am Psychol 1997; 52(10): 1059-69.

18 Schmidt $F$. The role of general cognitive ability and job performance: why there cannot be a debate. Hum Perform 2002; 15(1/2): 187-210.

19 Lee S, Buring JE, Cook NR, Grodstein F. The relation of education and income to cognitive function among professional women. Neuroepidemiology 2006; 26(2): 93-101.

20 Townsend P, Phillimore P, Beattie A. Health and Deprivation: Inequality and the North. Croom Helm, 1988
21 Office of National Statistics. Standard Occupational Classification 2000. The Stationery Office, 2000.

22 Benjamini J, Hochberg J. Controlling the false discovery rate: a practical and powerful approach to multiple testing. J R Stat SOC B 1995; 57(1): 12.

23 Jacquemont S, Reymond A, Zufferey F, Harewood L, Walters RG, Kutalik Z, et al. Mirror extreme BMI phenotypes associated with gene dosage at the chromosome 16p11.2 locus. Nature 2011; 478(7367): 97-102.

24 Huguet G, Schramm C, Douard E, Jiang L, Labbe A, Tihy F, et al. Measuring and estimating the effect sizes of copy number variants on general intelligence in community-based samples. JAMA Psychiatry 2018; 75(5): 447-57.

25 Fry A, Littlejohns TJ, Sudlow C, Doherty N, Adamska L, Sprosen T, et al. Comparison of sociodemographic and health-related characteristics of UK biobank participants with those of the general population. Am J Epidemiol 2017; 186(9): 1026-34.

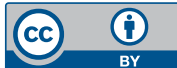

\title{
Reflections
}

\section{Reflections on The Elementary Forms of Religious Life}

\author{
George Ikkos and Daniel McQueen
}

The Elementary Forms of Religious Life was first published in 1912. It is a text that relies on accounts by others of pre-20th century lives of Australian Aborigines. It was written by Emile Durkheim (1858-1917), the son of a 3rd generation rabbi, who himself was a committed Atheist. Durkheim was a philosopher by training and, initially a Lycée teacher, he remained a pedagogue throughout life. He was the first appointed French professor of sociology, initially in Bordeaux and then in Paris. He is better known to psychiatrists for his book Suicide (1897); he formed a formidable research team and published a succession of seminal works including The Division of Labour in Society (1893) and The Rules of Sociological Method (1895), and established the foundational and still-live professional journal L'Année Sociologique. His associates peopled the chairs of social science departments across France and beyond.

Elementary Forms is armchair sociology at its best. Having considered religion to be the foundation of anything that might be legitimately called society, Durkheim relished the opportunity to make sense of what was the best available living evidence of the earliest origins of religion. Dismissing psychologistic and animistic explanations in this book, he sought understanding in social facts. There are careful descriptions of the terms clan, tribe, totem and religion (transcendental or not). He also describes the nature of the sacred and profane, the soul and magic. Durkheim made the then radical claim that the minds of Aborigines were no less sophisticated than those of contemporary Europeans. In this book Durkheim claimed that Totemism, which relies on the perception of and belief in specific affinities and distinctions between different individuals, clans, tribes, objects and natural phenomena, was the first step towards modern science.

Totemism and science share the categorising of observed phenomena, making causal inferences and depending on peer consensus. He saw the experience of the sacred and the rise of Totemism as a response to the bewildering intensity of feeling experienced by family groups, normally living isolated and dull lives, when they came together with others in larger groups. He referred to observers' reports of their appearing overpowered and running wild, gesticulating, copulating or aggressing as each small group joined others. In the face of such 'effervescence' they developed beliefs in a superior force (he adopts the Melanesian word 'mana' for this). Mana penetrates people and connects them to others and their environment. He argued that, though serving as foundation of religious belief, it is not perceived as transcendental, ergo religion is a natural social phenomenon.

The book's most profound implication is that organised social existence and Totemism imply each other and, through the experience of effervescence and the practice of ritual, Totemism encompasses the activities through which social meaning is expressed. Though education and convention have moderated our responses over time - street gangs; the attraction of presidential inaugurations and royal weddings; moral panics; epidemic hysterias; and clusters of cult suicides - even our own experiences at conferences and at work confirm the enduring importance of mana (and effervescence) in our daily life.

Reflecting a dedicated study of evidence and illuminated by brilliant conceptual analysis, Elementary Forms remains a work of formidable originality and immediate relevance, and is the best introduction to understanding in abstract and concrete detail the living force of the 'social' in the biopsychosocial model of psychiatry.

Copyright @ The Royal College of Psychiatrists 2019 